\title{
Risk factors for the syndrome of ventricular enlargement with gait apraxia (idiopathic normal pressure hydrocephalus): a case-control study
}

\author{
M CASMIRO, R D'ALESSANDRO, F M CACCIATORE, R DAIDONE, F CALBUCCI,* \\ E LUGARESI
}

From the Institute of Neurology, University of Bologna, and the Neurosurgical Division, ${ }^{*}$ Bellaria Hospital, Bologna, Italy

SUMMARY A case-control study was performed to verify the association between the risk factors for cerebrovascular disease and the syndrome of ventricular enlargement with gait apraxia (VEGAS). This syndrome was defined on the basis of clinical and CT criteria alone; however, it may be representative of patients with idiopathic normal pressure hydrocephalus in whom gait disturbance is the initial symptom. Seventeen patients were matched for age and sex with one hospitalised and two general population controls. Among the risk factors considered we found a significant statistical association between VEGAS and hypertension (odds ratio $=3 \cdot 14 ; p=0.032$ ), ischaemic heart disease (odds ratio $=4 \cdot 20 ; p=0.013$ ), $E C G$ ischaemic changes (odds ratio $=3.67 ; p=0.029$ ), low HDL-cholesterol levels (odds ratio $=3 \cdot 75 ; p=0.028$ ) and diabetes (odds ratio $=6.00 ; p=0.018$ ). Our findings indicate that risk factors for cerebrovascular disease may play a role in the development of VEGAS.

Normal pressure hydrocephalus (NPH) is characterised by a clinical triad (gait disturbance, impairment of mental function and sphincteric incontinence) associated with neuroimaging findings of nonobstructive ventricular enlargement. Reversal of the symptomatology by a shunt is another important feature. ${ }^{1-5}$

NPH has been traditionally divided into secondary and idiopathic forms. ${ }^{5}$ The former is related to head trauma, meningitis or subarchnoid hemorrhage but the aetiology and pathogenesis of idiopathic normal pressure hydrocephalus (INPH) remain uncertain.

The pathogenesis of INPH has traditionally been attributed to a low-grade asymptomatic meningeal disease causing meningeal thickening over the convexity of the cerebral hemispheres and resulting in reduced CSF reabsorption. ${ }^{6} \mathrm{~A}$ chronic inflammatory meningeal disease has been hypothesised, ${ }^{6}$ but not proved. A correlation between INPH and cerebrovascular disease has been proposed, ${ }^{7}$ based on

Address for correspondence: Roberto d'Alessandro, MD, Clinica Neurologica, Via U. Foscolo 7, 40123 Bologna, Italy.

Received 3 June 1988 and in final revised form 31 January 1989. Accepted 17 February 1989 anatomopathological and clinical correlations. Cerebrovascular changes have been reported in eight out of ten cases studied pathologically; ${ }^{7-11}$ these changes mainly consisted of atherosclerosis of cerebral vessels, lacunar and cystic infarctions, microinfarctions, concentric hypertrophy, hyalinosis and fibrinoid necrosis of the small intraparenchymal arteries, arteriolar and capillary sclerosis and demyelination areas.

Clinical correlates of INPH have included hypertension, ${ }^{1791012-14}$ diabetes, ${ }^{710}$ heart disease, ${ }^{78}$ obesity, ${ }^{47}$ and cerebrovascular disease. ${ }^{71014}$ Graff-Radford and Godersky ${ }^{12}$ recently stressed the association between INPH and hypertension. Earnest et al $^{7}$ described in detail two patients with INPH who showed gross pathological findings typical of cerebrovascular disease (but no fibrosis) and numerous old microscopic bilateral infarctions in the basal ganglia (clinically asymptomatic). On the basis of these findings they hypothesised that hypertensive vascular disease with multiple deep cerebral infarctions may be the initial pathological process in some cases of INPH, acting through a reduction of tissue bulk and tensile strength of the periventricular white matter and basal ganglia, together with an increased intraventricular CSF pulse pressure due to hypertension. In order to investigate 
this hypothesis we performed a case-control study aimed at verifying if risk factors for cerebrovascular disease were also risk factors for INPH.

\section{Methods}

\section{Cases: Diagnostic criteria}

The cases had to satisfy the following diagnostic criteria: (a) A clinical picture of INPH (gait disturbance with or without impairment of mental function and urinary incontinence) and as the first symptom a gait disturbance characterised by shortened steps, slowed rate of steppage and scuffing feet, widened base and frequent falling (so-called "gait apraxia"). ${ }^{3}$ Impairment of mental function was assessed on the Blessed dementia scale; ${ }^{15}$ (b) A CT scan showing (1) dilatation of the ventricular system without obstruction, (2) obliteration of the cerebral sulci at the convexity, (3) areas of periventricular low density and (4) "rounding" of the frontal horns of the lateral ventricles. ${ }^{16}$ We excluded patients whose clinical history suggested a possible aetiology for NPH (head trauma, meningitis and subarachnoid haemorrhage).

\section{Cases: inclusion criteria}

To avoid possible bias we included in the study all patients consecutively admitted between December 1986 and February 1988 because of a gait disturbance, provided that the gait disturbance was the primary reason for seeking medical care. We therefore excluded from the study patients affected by gait disturbance but primarily seen for other neurological or non-neurological symptoms (such as TIAs, myocardial infarction).

\section{Controls}

Each case was paired to three controls, matched for sex and age (an age range of \pm 3 years, with respect to each case, was chosen). One of these controls was represented by every next patient admitted because of a neurological disease not known to be related to the risk factors for cerebrovascular disease. Diagnoses of these hospitalised controls are shown in table 1. Each of these subjects underwent CT. The two other controls were randomly chosen among the general population of Bologna, using the General Registry Office lists. These subjects were contacted by telephone and asked to come forward for a free medical examination. Agreement was about $70 \%$. The protocol required the exclusion from general population controls of those subjects who suffered from gait disturbance, since for ethical reasons we did not perform CT in this population group. However, nobody had to be excluded for this reason.

\section{Risk factors}

The following risk factors were evaluated:

Hypertension: blood pressure values exceeding 160 and/or 95 $\mathrm{mm} \mathrm{Hg}$ on at least three different measurements, or treatment with antihypertensive drugs, irrespective of blood pressure values; Ischaemic heart disease: documented previous clinical admissions for myocardial ischaemic disease; Ischaemic ECG changes: at the time of examination both cases and controls had a standard ECG record. Each ECG was evaluated independently by two "blind" expert cardiologists, and only concordant reports of ischaemic myocardial changes were accepted; $H D L$-cholesterol levels:
Table 1 Diagnoses of hospitalised controls

\begin{tabular}{|c|c|c|}
\hline $\begin{array}{l}\text { Control } \\
\text { No }\end{array}$ & $\begin{array}{l}\text { Age/Sex } \\
\text { (years) }\end{array}$ & Diagnosis \\
\hline 1 & $73 / \mathrm{M}$ & Amyotrophic lateral sclerosis \\
\hline 2 & $68 / \mathrm{M}$ & Meningioma of falx \\
\hline 3 & 73 / M & Amyotrophic lateral sclerosis \\
\hline 4 & $65 / \mathrm{M}$ & Acute disseminated encephalomyelitis \\
\hline 5 & $63 / \mathrm{M}$ & Cervical spondylosis with myelopathy \\
\hline 6 & $75 / F$ & Idiopathic sensorimotor polyneuropathy \\
\hline 7 & $75 / \mathrm{M}$ & Amyotrophic lateral sclerosis \\
\hline 8 & $64 / M$ & Ocular myasthenia \\
\hline 9 & $64 / M$ & Orthostatic tremor \\
\hline 10 & $71 / \mathbf{M}$ & $\begin{array}{l}\text { Metastatic spinal cord compression from lung } \\
\text { carcinoma }\end{array}$ \\
\hline 11 & $76 / \mathrm{F}$ & Chronic polyradiculoneuritis \\
\hline $\begin{array}{l}12 \\
13\end{array}$ & $\begin{array}{l}67 / \mathrm{F} \\
69 / \mathrm{M}\end{array}$ & $\begin{array}{l}\text { Ocular myopathy } \\
\text { Cerebral metastasis from lung carcinoma }\end{array}$ \\
\hline 14 & $71 / \mathrm{M}$ & Progressive supranuclear palsy \\
\hline 15 & $66 / \mathrm{F}$ & Idiopathic multiple mononeuropathy \\
\hline 16 & $78 / \mathrm{M}$ & $\begin{array}{l}\text { Brachial plexus metastatic infiltration from } \\
\text { lung carcinoma }\end{array}$ \\
\hline 17 & $69 / \mathrm{M}$ & Amyotrophic lateral sclerosis \\
\hline
\end{tabular}

reduced fasting blood high density lipoprotein (HDL)cholesterol levels (below lower limits: $35 \mathrm{mg} / 100 \mathrm{ml}$ for males and $45 \mathrm{mg} / 100 \mathrm{ml}$ for females); Diabetes: fasting blood glucose levels were determined; values exceeding upper normal limits $(110 \mathrm{mg} / 100 \mathrm{ml})$ or treatment with hypoglycaemic drugs; Transient ischaemic attacks (TIAs): only documented or highly suggestive episodes of transient ischaemic cerebral attacks were considered; Obesity: body mass estimate as a risk factor was carried out by means of the Body Mass Index (BMI $=$ weight $/$ height $^{2}$ expressed as $\mathrm{kg} /$ $\mathrm{m}^{2}$ ) and obesity was defined on the basis of a BMI value exceeding $27 \mathrm{~kg} / \mathrm{m}^{2}$; Smoking: present or past smoking habits were taken into account, irrespective of daily number of cigarettes smoked or duration of smoking habit; Alcohol: although alcohol is not considered a risk factor for cerebrovascular disease, we took it into account because of some reports in the literature of an association with INPH; 9 daily alcohol consumption was estimated from questioning, and approximate volume values were converted into daily grams consumption using conversion tables of the Italian Istituto Nazionale della Nutrizione; a daily consumption exceeding $\mathbf{5 0}$ grams was considered.

\section{Treatment of patients}

A test removal of $20-30 \mathrm{ml}$ cerebrospinal fluid was performed, according to Fisher, ${ }^{17}$ whenever patients agreed. Furthermore, each patient whose general condition made surgical treatment possible was referred for further investigations (RISA $^{18}$ and infusion manometric tes ${ }^{19}{ }^{19}$; if results from these examinations showed inversion of CSF flow, a ventriculoatrial shunt was performed. All patients underwent physiotherapy.

\section{Statistical analysis}

Data analysis was carried out calculating odds ratios and $p$ values by means of the Mantel-Haenszel matched chi-square test for multiple controls. ${ }^{20}$ Comparison between hospitalised and general population controls was performed by means of Fisher's exact test. 


\section{Results}

The study included 17 patients with INPH (13 males and four females; mean age $=69.65$ years, range 6278 years) and 51 controls (mean age 70.25 years, range 63-79). General features of the patients are summarised in table 2.

As regards mental impairment, the mean value of Blessed score was $4 \cdot 26$, ranging from 0 to $14 \cdot 5$; only six cases had a Blessed score over 4 .

Six patients underwent RISA and an infusion manometric test: in each inversion of CSF flow was found and in four patients a ventriculo-atrial shunt was performed. The effect of treatment was assessed both on clinical grounds and by the subjective evaluations of patients and their relatives. Three patients showed marked improvement of gait disturbance at follow-up (six months later); the fourth (case 15) had a poor result. In another nine patients a CSF removal test was performed: in eight improvement of gait disturbance (from slight to marked) was achieved.

The associated CT scan findings were mainly ischaemic lacunes, found in five cases; slight atrophy was present in three cases and a cyst of the septum pellucidum in two. By comparison, among hospitalised controls we found ischaemic lacunes in one case and slight atrophy in five.

\section{Risk factors}

There were no statistically significant differences in risk factors among the two control populations (table 3).
Table 3 Risk factors among controls

\begin{tabular}{|c|c|c|c|}
\hline \multirow[b]{2}{*}{ Risk factor } & \multirow[b]{2}{*}{$\begin{array}{l}\text { Hospitalised } \\
\text { controls } \\
(n=17)\end{array}$} & \multirow[b]{2}{*}{$\begin{array}{l}\text { Healthy } \\
\text { controls } \\
(n=34)\end{array}$} & \multirow{2}{*}{$\begin{array}{l}\text { Fisher's exact test } \\
\text { Hospitalised versus } \\
\text { healthy controls } \\
\text { ( } p \text { value) }\end{array}$} \\
\hline & & & \\
\hline \multirow{9}{*}{$\begin{array}{l}\text { Hypertension } \\
\text { Ischaemic heart } \\
\text { disease } \\
\text { ECG ischaemic } \\
\text { changes } \\
\text { HDL-cholesterol } \\
\text { levels } \\
\text { Diabetes } \\
\text { TIAs } \\
\text { Obesity } \\
\text { Smoking } \\
\text { Alcohol }\end{array}$} & $6(35 \%)$ & $12(35 \%)$ & 0.625 \\
\hline & $2(12 \%)$ & $6(18 \%)$ & 0.459 \\
\hline & $6(35 \%)$ & $11(32 \%)$ & 0.536 \\
\hline & $3(18 \%)$ & $1(3 \%)$ & $0 \cdot 102$ \\
\hline & & $2(6 \%)$ & 0.439 \\
\hline & $0-$ & $1(3 \%)$ & 0.666 \\
\hline & $2(12 \%)$ & $10(29 \%)$ & $0 \cdot 146$ \\
\hline & $10(59 \%)$ & $16(47 \%)$ & 0.311 \\
\hline & $7(41 \%)$ & $8(24 \%)$ & $0 \cdot 164$ \\
\hline
\end{tabular}

As far as the cases are concerned, odds ratios and $p$ values for the risk factors under examination are shown in table 4.

As can be seen, a significant association $(p<0.05)$ was found between INPH and hypertension, ischaemic heart disease, ECG ischaemic changes, reduced HDL-cholesterol levels and diabetes. There was not a significant association with the other factors under examination.

\section{Discussion}

This study was mainly concerned with the "special clinical problem" of idiopathic normal pressure hydrocephalus (INPH). Since Hakim and Adams' ${ }^{\prime 4}$

Table 2 General features of cases

\begin{tabular}{|c|c|c|c|c|c|}
\hline Patients & Sex & $\begin{array}{l}\text { Age at } \\
\text { admission } \\
(y r)\end{array}$ & $\begin{array}{l}\text { Age at onset } \\
\text { of gait } \\
\text { disturbance }\end{array}$ & Blessed score & Sphincteric disturbances \\
\hline $\begin{array}{l}1 \\
2\end{array}$ & $\begin{array}{l}\mathbf{M} \\
\mathbf{M}\end{array}$ & $\begin{array}{l}72 \\
70\end{array}$ & $\begin{array}{l}69 \\
69\end{array}$ & $\begin{array}{c}4 \\
13 \cdot 5\end{array}$ & $\begin{array}{l}\text { Urinary urgency } \\
\text { Urinary incontinence }\end{array}$ \\
\hline $\begin{array}{l}3 \\
4 \\
5 \\
6\end{array}$ & $\begin{array}{l}\mathrm{M} \\
\mathrm{M} \\
\mathrm{M} \\
\mathrm{F}\end{array}$ & $\begin{array}{l}72 \\
64 \\
63 \\
72\end{array}$ & $\begin{array}{l}72 \\
63 \\
63 \\
70\end{array}$ & $\begin{array}{l}4 \cdot 5 \\
2 \\
2 \cdot 5 \\
0\end{array}$ & $\begin{array}{l}\text { Absent } \\
\text { Urinary urgency } \\
\text { Urinary incontinence } \\
\text { Absent }\end{array}$ \\
\hline 7 & $\mathbf{M}$ & 72 & 71 & $3 \cdot 5$ & Absent \\
\hline 8 & $\mathbf{M}$ & 62 & 62 & 1.5 & Urinary urgency \\
\hline 9 & $\mathbf{M}$ & 66 & 65 & 5 & Urinary urgency and urinary incontinence \\
\hline $\begin{array}{l}10 \\
11\end{array}$ & $\begin{array}{l}\mathrm{M} \\
\mathrm{F}\end{array}$ & $\begin{array}{l}73 \\
73\end{array}$ & $\begin{array}{l}70 \\
72\end{array}$ & $\begin{array}{l}4 \\
3 \cdot 5\end{array}$ & $\begin{array}{l}\text { Urinary urgency } \\
\text { Urinary incontinence }\end{array}$ \\
\hline
\end{tabular}


Table 4 Results of case-control study

\begin{tabular}{|c|c|c|c|c|c|c|c|c|c|c|}
\hline \multirow[b]{2}{*}{ Risk factor } & \multicolumn{10}{|c|}{ Outcome among case-control quadruplets (case, control 1, control 2, control 3)* } \\
\hline & +--- & $\begin{array}{l}++-- \\
+-+- \\
+--+\end{array}$ & $\begin{array}{l}+++- \\
++-+ \\
+-++\end{array}$ & ++++ & ---- & $\begin{array}{l}-+-- \\
--+- \\
---+\end{array}$ & $\begin{array}{l}-++- \\
-+-+ \\
--++\end{array}$ & -+++ & Odds ratio & $p V$ \\
\hline $\begin{array}{l}\text { Hypertension } \\
\text { Ischaemic heart disease } \\
\text { ECG ischaemic changes } \\
\text { HDL-cholesterol levels } \\
\text { Diabetes } \\
\text { TIAs } \\
\text { Obesity } \\
\text { Smoking } \\
\text { Alcohol }\end{array}$ & $\begin{array}{l}4 \\
5 \\
2 \\
5 \\
4 \\
2 \\
3 \\
1 \\
3\end{array}$ & $\begin{array}{l}4 \\
3 \\
7 \\
0 \\
0 \\
0 \\
3 \\
4 \\
3\end{array}$ & $\begin{array}{l}2 \\
0 \\
2 \\
0 \\
0 \\
0 \\
0 \\
3 \\
1\end{array}$ & $\begin{array}{l}1 \\
0 \\
0 \\
0 \\
0 \\
0 \\
0 \\
1 \\
0\end{array}$ & $\begin{array}{r}2 \\
4 \\
2 \\
9 \\
11 \\
14 \\
5 \\
1 \\
5\end{array}$ & $\begin{array}{l}1 \\
5 \\
2 \\
2 \\
2 \\
1 \\
4 \\
1 \\
1\end{array}$ & $\begin{array}{l}3 \\
0 \\
2 \\
1 \\
0 \\
0 \\
1 \\
6 \\
3\end{array}$ & $\begin{array}{l}0 \\
0 \\
0 \\
0 \\
0 \\
0 \\
1 \\
0 \\
1\end{array}$ & $\begin{array}{l}3 \cdot 14 \\
4 \cdot 20 \\
3 \cdot 67 \\
3 \cdot 75 \\
6 \cdot 00 \\
6.00 \\
1 \cdot 67 \\
1.08 \\
1 \cdot 60\end{array}$ & $\begin{array}{l}0.03 \\
0.01 \\
0.02 \\
0.02 \\
0.01 \\
0.09 \\
0.3 \\
0.8 \\
0.3\end{array}$ \\
\hline 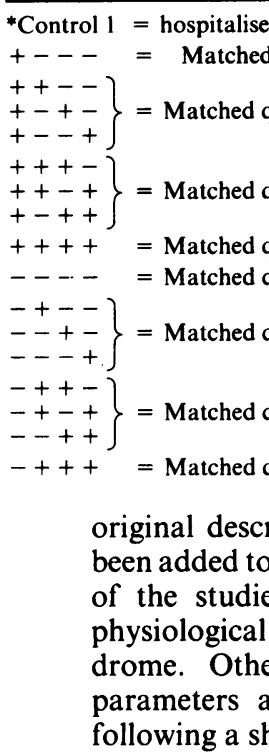 & $\begin{array}{l}\text { ts with ris } \\
\text { with risk } \\
\text { with risk } \\
\text { with risk } \\
\text { with risk } \\
\text { with risk } \\
\text { with risk } \\
\text { with risk } \\
\text { f this } \mathrm{s} \\
\text { rrstandi } \\
\text { is topic } \\
\text { iroimag } \\
\text { attem } \\
\text { to pr } \\
\text { tedure. }\end{array}$ & $\begin{array}{l}\text { factor absen } \\
\text { factor absen } \\
\text { ndrome } \\
\text { g of its a } \\
\text { have fo } \\
\text { ng aspec } \\
\text { ted to } \\
\text { dict a g }\end{array}$ & $\begin{array}{l}\text { in case and } \\
\text { in case and } \\
\text { ery little } \\
\text { iology. } \\
\text { used on } \\
\text { of the } \\
\text { lefine } \\
\text { od outc }\end{array}$ & $\begin{array}{l}\text { present in } \\
\text { present in } \\
\text { has } \\
\text { Most in } \\
\text { the re } \\
\text { syn- re } \\
\text { hich } \mathrm{m} \\
\text { come } \mathrm{m}\end{array}$ & $\begin{array}{l}\text { ls. }+=\text { Risk } \mathrm{f} \\
\text { in controls. } \\
\text { control. } \\
\text { rols. } \\
\text { trols. } \\
\text { rols. } \\
\text { one control. } \\
\text { two controls. } \\
\text { three controls } \\
\text { Neverthe } \\
\text { ng only } 40^{\circ} \\
\text { esults than } \\
\text { eason for } t \\
\text { nay reflect } \\
\text { nore, it m } \\
\text { eatures of }\end{array}$ & $\begin{array}{l}\text { eless, resu } \\
\% \text { positiv } \\
\text { in patie } \\
\text { this differ } \\
\text { different } \\
\text { ust be en } \\
\text { this synd }\end{array}$ & $\begin{array}{l}\text { lts are st } \\
\text { e respon } \\
\text { nts with } \\
\text { ence in } \\
\text { underlyi } \\
\text { nphasise }\end{array}$ & $\begin{array}{l}\text { unsatis } \\
\text { rs to sh } \\
\text { seconda } \\
\text { tcome i } \\
\text { mechar } \\
\text { that ev } \\
\text { not pr }\end{array}$ & $\begin{array}{l}\text { ctory, s } \\
\mathrm{t}^{5} \text { with v } \\
\text { " NPH. } \\
\text { uncertai } \\
\text { sms. Fur } \\
\text { the cli } \\
\text { isely def }\end{array}$ & 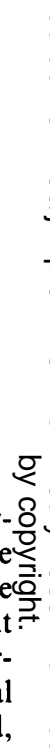 \\
\hline
\end{tabular}

\section{Associated CT findings}

\section{None}

Lacune of the anterior limb of the left internal capsule

None

None

None

Slight temporal atrophy; cyst of the septum pellucidum

None

Lacune of the genu of the right internal capsule; slight temporal atrophy

Lacune of the right internal capsule; cyst of the septum pellucidum

Bilateral parieto-occipital lacune

Slight frontal atrophy

Multiple lacunes of the centrum semiovalis

None

None

None

None

None
Treatment

Outcome

Shunt device

Shunt device

Shunt device

CSF test removal

CSF test removal

CSF test removal

CSF test removal (RISA and infusion manometric test positive but refusal) Refusal CSF removal

CSF test removal

Refusal CSF removal

CSF test removal (RISA and Katzman

positive: waiting for shunt)

Refusal CSF removal

CSF test removal

Refusal CSF removal

Shunt device

CSF test removal

CSF test remova
Excellent improvement

Good improvement

Good improvement

Moderate improvement

Moderate improvement

Transient improvement

Subjective improvement

Slight subjective improvement after hypertension control

Good improvement

Slight subjective improvement

Good improvement

Not modified

Transient improvement

Not modified

Transient improvement

Transient improvement

Excellent improvement 
and are limited to the general statement of a clinical triad ("a slowly progressive gait disorder, impairment of mental function and sphincteric incontinence"). ${ }^{2}$ The triad is not always present. Thus, the gait disturbance, may be the only obvious symptom ${ }^{1721}$ and, although the features are often of the so-called "gait apraxia" ${ }^{35}$ it has also been described as "spasticity" or even as a Parkinsonian feature. ${ }^{22} 23$ Fisher stated that "it is obviously easier to say what the gait disturbance is not than what it is". ${ }^{3}$ These uncertainties make it difficult to perform clinical studies on INPH because selection criteria can always be questioned to some degree.

In this study patients were included on the basis of clinical and CT criteria alone. The reasons for this were, first, it was not ethical to submit a patient to an invasive diagnostic procedure unless there was the possibility of surgical treatment, and, second, the need to avoid the possible bias arising from considering only patients in good general condition. A definitive diagnosis of INPH requires RISA and an infusion manometric test. Since we limited our diagnostic criteria, we think it correct to call this clinical pattern "Ventricular enlargement with gait apraxia syndrome" (VEGAS), which is what clinicians really see. However, the diagnostic criteria we adopted are highly relevant because an onset with gait disturbance of INPH has been correlated with a good outcome following a shunt procedure. ${ }^{34}$

In our study all patients showed an uniform clinical and CT picture and the six patients who underwent RISA and manometric infusion test showed patterns typical of INPH. On the other hand, these laboratory procedures have been judged as "often unnecessary with respect to the diagnosis of INPH if CSF removal test is positive". ${ }^{17}$ On the basis of these considerations we think that VEGAS is representative of a subgroup of patients with INPH and gait disturbance as first symptom.

In order to avoid possible selection bias we included only patients primarily seen because of gait disturbance. Also, we excluded from the study patients seen primarily because of other focal neurological symptoms suggesting cerebrovascular disease and showing a gait disturbance as well.

We found a significant association between the risk factors for atherosclerosis and VEGAS. This finding is in agreement with the hypothesis of Earnest et $\mathrm{al}^{7}$ that at least in some cases of INPH "a hypertensive vascular disease with multiple deep cerebral infarctions may be the initial pathological process." Furthermore our data confirm and extend the finding by Graff-Radford and Godersky ${ }^{12}$ of an association between INPH and hypertension. We cannot speculate on the pathogenesis of VEGAS but only on the aetiology; we cannot exclude that a meningeal thickening may play a role in the development of VEGAS but our findings showed more support for the hypothesis of Earnest et al. ${ }^{?}$

Further studies are needed of the mechanism by which cerebrovascular disease contributes to the development of this syndrome. If our findings are confirmed, future studies should be developed to verify whether optimal treatment of risk factors may improve the course of the disease. In any case, neurologists examining such patients will be aware of the need to screen them for potentially dangerous cardiovascular diseases.

We thank Pasquale Bernardi, MD and Michele Adamo, MD for their interpretation of ECG, and Ms Antonella Pollini for the expert secretarial assistance. This work was supported by the University of Bologna, grant N 12/6/C (60\%).

\section{References}

1 Adams RD, Fisher CM, Hakim S, et al. Symptomatic occult hydrocephalus with "normal" cerebrospinal fluid pressure (a treatable syndrome). $N$ Engl J Med 1965;273:117-26.

2 Adams RD, Victor M. Principles of Neurology, 3rd ed. New York: McGraw Hill, 1985:466-8.

3 Fisher CM. The clinical picture in occult hydrocephalus. Clin Neurosurg 1977;24:270-84.

4 Hakim S, Adams RD. The special clinical problem of symptomatic hydrocephalus with normal cerebrospinal fluid pressure. Observations on cerebrospinal fluid hydrodynamics. $J$ Neurol Sci 1965;2:307-27.

5 Katzman R. Normal pressure hydrocephalus. In: Wells CE, ed. Dementia. Philadelphia: FA Davis Co, 1977:69-92.

6 Adams RD. Recent observations on normal pressure hydrocephalus. Schweiz Arch Neurol Neurochir Psychiatr 1975;116: 7-15.

7 Earnest MP, Fahn S, Karp JH, Rowland LP. Normal pressure hydrocephalus and hypertensive cerebrovascular disease. Arch Neurol 1974;31:262-6.

8 DeLand FH, James AE Jr, Ladd DJ, Konigsmark BW. Normal pressure hydrocephalus: a histologic study. Am J Clin Pathol 1972;58:58-63.

9 Koto A, Rosenberg G, Zingesser LH, et al. Syndrome of normal pressure hydrocephalus: possible relation to hypertensive and arteriosclerotic vasculopathy. J Neurol Neurosurg Psychiatry 1977;40:73-9.

10 Lorenzo AV, Bresnan MJ, Barlow CF. Cerebrospinal fluid absorption deficit in normal pressure hydrocephalus. Arch Neurol 1974;30:387-93.

11 Vessal K, Sperber EE, James AE Jr. Chronic communicating hydrocephalus with normal CSF pressure: a cisternographicpathologic correlation. Ann Radiol (Paris) 1974;17:785-93.

12 Graff-Radford NR, Godersky JC. Idiopathic normal pressure hydrocephalus and systemic hypertension. Neurology 1987; 37:868-71.

13 Meyer JS, Kitagawa Y, Tanahashi N, et al. Evaluation of treatment of normal-pressure hydrocephalus. $J$ Neurosurg 1985;62:513-21.

14 Shukia D, Singh BM, Strobos RJ. Hypertensive cerebrovascular disease and normal pressure hydrocephalus. Neurology 1980; 30:998-1000.

15 Blessed G, Tomlinson BE, Roth M. The association between 
quantitative measures of dementia and of senile change in the cerebral grey matter of elderly subjects. Br J Psychiatry 1968; 114:797-811.

16 Vassilouthis J. The syndrome of normal-pressure hydrocephalus. J Neurosurg 1984;61:501-9.

17 Fisher CM. Communicating hydrocephalus. Lancet 1978;i:37.

18 Di Chiro G, Reames PM, Matthews WB Jr. RISA-ventriculography and RISA-cisternography. Neurology 1964;14:185-91.

19 Katzman R, Hussey F. A simple constant-infusion manometric test for measurement of CSF absorption: 1. Rationale and method. Neurology 1970;20:534-44.

20 Schlesselman JJ. Case-control studies. Design, conduct, analysis.
Chap 7, New York: Oxford University Press, 1982:216-20.

21 Fisher CM. Hydrocephalus as a cause of disturbances of gait in the elderly. Neurology 1982;32:1358-63.

22 Clough CG. A case of normal pressure hydrocephalus presenting as levodopa responsive Parkinsonism. J Neurol Neurosurg Psychiatry 1987;50:234.

23 Sypert GE, Leffman H, Ojemann GA. Occult normal pressure hydrocephalus manifested by parkinsonism-dementia complex. Neurology 1973;23:234-8.

24 Graff-Radford NR, Godersky JC. Normal-pressure hydrocephalus. Onset of gait abnormality before dementia predicts good surgical outcome. Arch Neurol 1986;43:940-2. 